\title{
COMPUTATIONAL STUDIES OF NEW MATERIALS
}




\section{This page is intentionally left blank}




\title{
COMPUTATIONAL STUDIES OF NEW MATERIALS
}

\author{
Editors
}

\section{Daniel A Jelski}

State University of New York, Fredonia

\section{Thomas F George}

University of Wisconsin-Stevens Point 


\section{Published by}

World Scientific Publishing Co. Pte. Ltd.

P O Box 128, Farrer Road, Singapore 912805

USA office: Suite 1B, 1060 Main Street, River Edge, NJ 07661

UK office: 57 Shelton Street, Covent Garden, London WC2H $9 \mathrm{HE}$

\section{British Library Cataloguing-in-Publication Data}

A catalogue record for this book is available from the British Library.

\section{COMPUTATIONAL STUDIES OF NEW MATERIALS}

Copyright $\odot 1999$ by World Scientific Publishing Co. Pte. Ltd.

All rights reserved. This book, or parts thereof, may not be reproduced in any form or by any means, electronic or mechanical, including photocopying, recording or any information storage and retrieval system now known or to be invented, without written permission from the Publisher.

For photocopying of material in this volume, please pay a copying fee through the Copyright Clearance Center, Inc., 222 Rosewood Drive, Danvers, MA 01923, USA. In this case permission to photocopy is not required from the publisher.

ISBN 981-02-3325-6

Printed in Singapore. 


\section{CONTENTS}

Preface

Introduction

Daniel A. Jelski and Thomas F. George

Ab Initio Studies of Compound Semiconductor Surfaces

Tapio T. Rantala

Molecular-Dynamics Studies of Defects and Impurities in Bulk

Semiconductors

Stefan K. Estreicher and Peter A. Fedders

Tight-Binding Molecular Dynamics Study of Structures and Dynamics of Carbon Fullerenes

C. Z. Wang, B. L. Zhang and K. M. Ho

Computations of Higher Fullerenes

Zdeněk Slanina, Xiang Zhao and Eiji Osawa

Relaxations of Charge Transfer and Photoexcitation in $\mathrm{C}_{60}$ and Polymers

Xin Sun, Guoping Zhang, Thomas F. George and R. T. Fu

Ionic Charge Transport in Molecular Materials: Polymer Electrolytes

Mark A. Ratner

Computational Approaches in Optics of Fractal Clusters

Vadim A. Markel and Vladimir M. Shalaev

Local Fields' Localization and Chaos and Nonlinear-Optical

Enhancement in Composites

Mark I. Stockman

Atomic Valences in Aperiodic Crystals Studies by the Bond Valence Method 
vi Contents

Surface Light-Induced Drift

Michael A. Vaksman

Theoretical Treatment of Surface Adsorbates

László Nánai, Csaba Beleznai and Thomas F. George

Phase Conjugation Through Four-Wave Mixing

Henk F. Arnoldus and Thomas F. George

Electromagnetic Propagators in Micro- and Mesoscopic Optics

Ole Keller

Nanoscale Materials: Conceptual and Computational Challenges

Mushti V. Ramakrishna

Index 


\section{PREFACE}

When World Scientific Publishers first approached us three years ago about editing a book on the overall topic of computational materials science, we were flattered but rather awed by the task. Since the project seemed interesting and timely, we agreed to do it. It soon became clear that we would have to narrow down the topic a bit. One possibility, for example, was a book titled Computational Methods in Materials Science. However, this would look different from the current volume: it would bristle with computer code, discuss the appropriateness of various basis sets, and be much more of a how-to manual for the computer set. We decided not to edit such a book, partly because we thought it would reach a rather narrow audience.

The title we have chosen, Computational Studies of New Materials, puts more emphasis on the materials and somewhat less on the computation. And that is indeed the way this book has evolved. The focus is on the materials, be they fullerenes, fractals or polymers. Of course, computational methods are not far below the surface, and in particular, the volume contains an excellent description of tight-binding methods. But it is our hope that this volume will adorn the shelves of scientists who are not explicitly computationalists.

We have found our contributors to be very good writers, interesting people, and above all, imaginative and talented scientists. Working with them has been a rewarding scientific adventure, and we thank every one of them for the hard work and effort they have devoted to this volume. We also thank Dr. Chi-Wai (Rick) Lee, Scientific Editor at World Scientific, for his guidance and encouragement throughout the course of this project. Finally, we gratefully acknowledge the staff and students in the Office of the Chancellor at UW-Stevens Point for assistance in assembling the index. 